\title{
Influence of diopside:feldspar ratio in ceramic reactions assessed by quantitative phase analysis (X-ray diffraction - Rietveld method)
}

\section{(Influência da razão diopsídio:feldspato em reações de cerâmica branca avaliada por análise quantitativa de fases (difratometria de raios $X$ - método de Rietveld))}

\author{
L. Kuzmickas ${ }^{1}$, F. R. D. Andrade', G. A. J. Szabó ${ }^{1}$, J. F. M. Motta', M. Cabral Jr' \\ ${ }^{l}$ Department of Mineralogy and Geotectonics, Geosciences Institute, S. Paulo University (IGc - USP), \\ SP 05508-080 \\ ${ }^{2}$ Section of Mineral Resources and Ceramic Technology, Institute for Technological Research of S. Paulo (IPT), \\ SP 05508-901 \\ lukuzmickas@gmail.com,dias@usp.br,gajszabo@usp.b,motta.jf@gmail.com,marsis@ipt.br
}

\begin{abstract}
White ceramics were produced with raw mixtures prepared with varying proportions of diopside-rich rock $(0$ to 20 wt. $\%)$ and potassic feldspar (40 to $20 \mathrm{wt} . \%$ ), and fixed proportions of kaolinite (40 wt.\%) and quartz (20 wt.\%), fired in a temperature range from 1170 to $1210{ }^{\circ} \mathrm{C}$. The phases identified in the experimental ceramics were quartz, anorthite, mullite and glass, and their relative mass proportions were determined by X-ray diffraction (Rietveld method). The addition of diopside as a partial substitute for potassic feldspar causes the formation of a calcium silicate, analogous of the natural anorthite $\left(\mathrm{CaSi}_{2} \mathrm{Al}_{2} \mathrm{O}_{8}\right)$ in the ceramics, with proportional reduction in its glass and mullite contents. Water absorption and porosity of the ceramic bodies clearly decrease with increasing firing temperature, while the effect of the raw mixture composition on the physical and mechanical properties of the ceramics is less evident. Diopside-rich rock has low iron content $\left(1.5 \mathrm{wt} . \% \mathrm{Fe}_{2} \mathrm{O}_{3}\right)$ and, therefore, promotes white burning.

Keywords: diopside, feldspar, ceramic, X-ray diffraction, Rietveld method.
\end{abstract}

\section{Resumo}

Foram produzidas cerâmicas brancas com matérias-primas preparadas com proporções variáveis de rocha rica em diopsídio (0 a $20 \%$ em peso) e feldspato potássico (40 a 20\% em peso), e proporções fixas de caulinita (40\% em peso) e quartzo (20\% em peso), queimadas em temperatura entre 1170 e $1210^{\circ} \mathrm{C}$. As fases identificadas nas cerâmicas experimentais foram quartzo, anortita, mulita e vidro, e suas proporções relativas em massa foram determinadas por difração de raios X (método de Rietveld). A adição de diopsídio em substituição parcial do feldspato potássico causa a formação nas peças cerâmicas de um silicato de cálcio análogo à anortita $\left(\mathrm{CaSi}_{2} \mathrm{Al}_{2} \mathrm{O}_{8}\right)$, com uma redução proporcional dos teores de vidro e mulita. A absorção de água e a porosidade das peças cerâmicas diminuem com o aumento da temperatura de queima, enquanto que o efeito da composição das matérias-primas nas propriedades físicas e mecânicas dos corpos cerâmicos é menos evidente. A rocha rica em diopsídio tem baixo teor de ferro(1,5\% em peso de $\mathrm{Fe}_{2} \mathrm{O}_{3}$ ) e, portanto, promove uma queima branca.

Palavras-chave: diopsídio, feldspato, cerâmica, difração de raios $X$, método de Rietveld.

\section{INTRODUCTION}

Diopside is widely recognized as a raw material for glass-ceramic, due to its relatively low melting point and the low viscosity of the melt. The use of diopside-rich rock, replacing up to $20 \mathrm{wt} \%$ of the potassic feldspar added to ceramic bodies improves their technical features, reducing water absorption while maintaining constant the drying linear retraction and increasing the flexural resistance, for porcelains produced at low temperature. The use of diopside, not only on ceramic, was investigated in the past by several authors [1-6]. In Brazil, however, studies of technological application of diopside-rich rock are still restricted [7-9].

Diopside-rich rock used in the present study was collected in Castro Alves district (Bahia, northeastern Brazil). The geological setting of the area refers to the S. Francisco Craton, with metamorphic rocks of granulite to high amphibolite facies that belong to the Jequié and Caraíba Complexes. The Caraíba Complex has lense-shaped bodies of diopside-rich rock, which may reach up to $700 \mathrm{~m}$ in length and $200 \mathrm{~m}$ in width, usually aligned in the NW-SE direction. These diopside-rich rocks are deformed and cut by granites and pegmatites, with intrusive breccias and veins. Diopsiderich rock is mainly composed by diopside, with minor amounts of tremolite, feldspar, quartz, carbonates, titanite, garnet, epidote and tourmaline - nevertheless, the wholerock chemical composition is close to the stoichiometric composition of diopside $\left(\mathrm{MgCaSi}_{2} \mathrm{O}_{6}\right)$. 
Crystalline phases of the ceramic bodies were identified by X-ray diffraction (XRD) and their weight proportion in each sample, together with the amount of the amorphous phase (glass), were determined by the Rietveld method [1214]. This method is based on the calculation of simulated $\mathrm{X}$-ray diffractograms, which are step by step refined in order to match the observed diffractogram (actual data). The simulated X-ray diffractogram is calculated considering the instrumental parameters used in data collection and the crystallographic information of the phases present in the sample. Although a non-crystalline phase lacks diffraction peaks, it is possible to determine its weight proportion in a mixture using the Riteveld method combined with the addition of an internal standard, a procedure described by [15].

In the present study, the use of diopside-rich rock was tested in white ceramics together with quartz and feldspar from Castro Alves pegmatites [10] and ceramic clays from the Recôncavo Basin, Bahia [11], fired in the temperature range from 1170 to $1210{ }^{\circ} \mathrm{C}$, according to procedures described below.

\section{EXPERIMENTAL}

Five series of mixtures of clay, feldspar, quartz and diopside-rich rock have been prepared and fired under oxidizing conditions at 1170 (T1), 1180 (T2), 1190 (T3), 1200 (T4) and $1210{ }^{\circ} \mathrm{C}$ (T5). Raw mixtures contain clay (40 $\mathrm{wt} \%)$, quartz $(20 \mathrm{wt} \%)$ and several proportions of potassic feldspar (KF) and diopside-rich rock (di): M1 = 40 wt.\% KF; M2 = 35 wt. $\% \mathrm{KF}+5$ wt. $\%$ di; M3 = 30 wt. $\% \mathrm{KF}+$ 10 wt. $\%$ di; M4 $=25$ wt. $\% \mathrm{KF}+15$ wt. $\%$ di; M5 $=20$ wt. $\% \mathrm{KF}+20$ wt. $\%$ di). Samples are labeled according to raw mix composition and temperature, for instance sample M2T3 means a raw mix M2 (40 wt.\% clay, 20 wt. \% quartz, 35 wt. $\%$ KF, 5 wt. $\%$ di) burned at T3 $\left(1190^{\circ} \mathrm{C}\right)$. The ceramic samples are straight prisms with dimensions of $60 \mathrm{~mm} \times 20$ $\mathrm{mm} \times 5 \mathrm{~mm}$, weighing about $15 \mathrm{~g}$, molded in a hydraulic press with $300 \mathrm{kgf} / \mathrm{cm}^{2}$ (29.4 MPa).

The following physical and mechanical characteristics of the ceramics were determined: drying linear retraction (\%), flexural resistance (MPa), water absorption (wt.\%) and apparent porosity (\%). Determination of water absorption and apparent porosity was made according to ISO 105453 standard procedure [16], while the analysis of flexural resistance was made according to ISO 10545-4 [17]. Drying linear retraction $(D L R)$ was calculated by expression:

$$
\operatorname{DLR}=\left[\left(\mathrm{L}_{\mathrm{s}}-\mathrm{L}_{\mathrm{q}}\right) / \mathrm{L}_{\mathrm{s}}\right] \times 100
$$

where $L \mathrm{~s}$ is the length of the ceramic body measured after drying at $110{ }^{\circ} \mathrm{C}$ and before firing, while $L_{q}$ is the length after firing.

The chemical composition of the raw materials determined by X-ray fluorescence is presented in Table I.

XRD analysis of the raw materials indicates that the clay is composed mainly by kaolinite, with trace amounts
Table I - Chemical composition of raw materials. [Tabela I - Composição química das matérias-primas.]

\begin{tabular}{lcccc}
\hline $\mathrm{wt.} \%$ & clay & $\begin{array}{c}\text { diopside-rich } \\
\text { rock }\end{array}$ & feldspar & quartz \\
\hline $\mathrm{SiO}_{2}$ & 64.60 & 51.4 & 64.9 & 99.00 \\
$\mathrm{Al}_{2} \mathrm{O}_{3}$ & 21.99 & 3.4 & 18.7 & 0.15 \\
$\mathrm{Fe}_{2} \mathrm{O}_{3}$ & 2.30 & 1.57 & $<0.10$ & $<0.1$ \\
$\mathrm{MnO}$ & n.d & 0.34 & $<0.10$ & n.d \\
$\mathrm{MgO}$ & 0.28 & 16.7 & $<0.10$ & $<0.1$ \\
$\mathrm{CaO}$ & 0.02 & 24.4 & 0.10 & $<0.1$ \\
$\mathrm{Na}{ }_{2} \mathrm{O}$ & 0.05 & 0.21 & 3.71 & $<0.1$ \\
$\mathrm{~K}_{2} \mathrm{O}$ & 0.51 & 0.1 & 10.8 & $<0.1$ \\
$\mathrm{TiO}_{2}$ & 1.41 & 0.1 & $<0.10$ & $<0.1$ \\
$\mathrm{P}_{2} \mathrm{O}_{5}$ & $n . d$ & $<0.10$ & $<0.10$ & n.d \\
$\mathrm{PF}$ & 7.91 & 1.6 & 0.85 & 0.23 \\
\hline
\end{tabular}

of illite and quartz, while potassium feldspar corresponds to microcline. Composition of the diopside-rich rock was determined by optical petrography and comprises mainly diopside, with trace amounts of tremolite, quartz and carbonate.

Powder samples of ceramic bodies were analysed in a Panalytical Empyrean X-ray diffractometer, with Cukalpha radiation, $40 \mathrm{~mA}, 45 \mathrm{kV}$, fixed divergent slit $\left(0.25^{\circ}\right)$ in an angular range from 3 to $90^{\circ} 2 \theta$, step size $0.02^{\circ}$, at room conditions. Quantitative phase analysis was made by XRD-Rietveld method of ceramic bodies fired at 1170 (T1), 1190 (T3), and $1210{ }^{\circ} \mathrm{C}$ (T5). An internal standard (15 wt.\% $\mathrm{TiO}_{2}$, rutile) was added to the powder samples in order to determine their amorphous phase (glass) content, according to the procedure described by [15]. Rietveld refinements were made with High Score Plus 3.0 (Panalytical). The refinement strategy included: (1) automatic background determination [18]; (2) peak search [19]; (3) insertion of individual phases and refinement of their scale factor [20]; (4) sample displacement correction after insertion of rutile structure (internal standard) - sample displacement is measured perpendicularly to the sample surface and causes a shift in peak position which is positive if the sample is high in a vertical goniometer system and negative if the sample is low; (5) refinement of cell parameters and scale factors of all phases together; (6) followed by refinement of peak assymetry and extinction [21] of quartz only. The peak profile function used was pseudo-Voigt. The following crystallographic information files (CIF) for identified phases were used: rutile (internal standard) [22], quartz [23], anorthite [24], mullite [25], diopside [26], cordierite [27].

\section{RESULTS AND DISCUSSION}

Phase composition of the ceramic bodies is presented in Table II and Fig. 1. X-ray diffractograms of ceramic bodies of all series, M1 to M5, fired at $1210{ }^{\circ} \mathrm{C}(\mathrm{T} 5)$ are shown in Fig. 2; a selected angular interval ( 15 to $30^{\circ} 2 \theta$ ) was chosen 
Table II - Phase composition of ceramic bodies determined by XRD-Rietveld and respective water absorption, apparent porosity, linear retraction and flexure resistance. Agreement indexes of Rietveld refinement (Rwp - weighted residue; GOF goodness of fit $=\theta^{2}$ )are shown; for further detail, see [14].

[Tabela II - Composição das fases dos corpos cerâmicos determinadas pelo método de Rietveld-DRX e respectivos dados de absorção de água, porosidade aparente, retração linear e resistência à flexão. Os indicadores estatísticos de qualidade dos refinamentos pelo método de Rietveld (Rwp-resíduo ponderado; GOF-qualidade da convergência $=\theta^{2}$ ) são apresentados; para maiores detalhes, consulte [14].]

\begin{tabular}{lcccccccccccccccc}
\hline & M1T1 & M1T3 & M1T5 & M2T1 & M2T3 & M2T5 & M3T1 & M3T3 & M3T5 & M4T1 & M4T3 & M4T5 & M5T1 & M5T3 & M5T5 \\
\hline $\begin{array}{l}\text { quartz } \\
\text { (wt.\%) }\end{array}$ & 31.5 & 30.2 & 31.2 & 29.9 & 29.8 & 29.5 & 25.3 & 25.6 & 19.5 & 24.4 & 23.6 & 22.5 & 28.6 & 22.4 & 18.6 \\
$\begin{array}{l}\text { anorthite } \\
\text { (wt.\%) }\end{array}$ & 2.5 & 2.1 & 2.8 & 4.9 & 5.2 & 4.2 & 15.5 & 15.1 & 9.9 & 23.6 & 23.9 & 19.6 & 26.2 & 26.2 & 22.5 \\
$\begin{array}{l}\text { mullite } \\
\text { (wt.\%) }\end{array}$ & 12.4 & 14.2 & 15.9 & 13.2 & 13.4 & 16.4 & 10.8 & 10.7 & 10.4 & 5.9 & 5.9 & 5.9 & 7.8 & 9.2 & 8.6 \\
$\begin{array}{l}\text { diopside } \\
\text { (wt.\%) }\end{array}$ & 0.0 & 0.0 & 0.0 & 0.0 & 0.0 & 0.0 & 0.0 & 0.0 & 0.0 & 0.0 & 0.0 & 0.0 & 5.1 & 0.0 & 0.0 \\
$\begin{array}{l}\text { cordierite } \\
\text { (wt.\%) }\end{array}$ & 0.0 & 0.0 & 0.0 & 0.0 & 0.0 & 0.0 & 0.0 & 0.0 & 0.0 & 0.8 & 1.3 & 3.8 & 0.0 & 0.0 & 0.0 \\
glass \\
$\begin{array}{l}\text { (wt.\%) } \\
\text { Rwp }\end{array}$ & 53.6 & 53.4 & 50.1 & 52.0 & 51.6 & 49.9 & 48.4 & 48.6 & 60.2 & 45.3 & 45.3 & 48.2 & 32.4 & 42.2 & 50.4 \\
$\begin{array}{l}\left.\text { GOF ( } \theta^{2}\right) \\
\text { water }\end{array}$ & 4.7 & 7.4 & 7.4 & 7.3 & 7.2 & 6.7 & 6.9 & 6.8 & 6.6 & 7.7 & 7.2 & 6.2 & 8.1 & 6.7 & 6.5 \\
$\begin{array}{l}\text { absorption } \\
\text { (\%) }\end{array}$ & 3.28 & 1.87 & 1.12 & 0.63 & 0.48 & 0.48 & 0.54 & 0.34 & 0.21 & 0.42 & 0.36 & 0.28 & 0.85 & 0.44 & 0.23 \\
$\begin{array}{l}\text { apparent } \\
\text { porosity } \\
\text { (\%) }\end{array}$ & 7.35 & 4.31 & 2.64 & 1.53 & 1.15 & 1.13 & 1.31 & 0.81 & 0.51 & 1.02 & 0.86 & 0.66 & 2.06 & 1.05 & 0.55 \\
$\begin{array}{l}\text { linear } \\
\text { retraction } \\
\text { (\%) }\end{array}$ & 7.31 & 7.91 & 8.47 & 9.64 & 9.28 & 9.48 & 9.57 & 8.94 & 9.34 & 8.16 & 7.73 & 8.06 & 9.16 & 8.79 & 6.40 \\
$\begin{array}{l}\text { flexure } \\
\text { resistance } \\
\text { (MPa) }\end{array}$ & 17.43 & 20.12 & 22.88 & 26.48 & 26.79 & 23.88 & 29.20 & 25.94 & 27.38 & 30.95 & 26.64 & 23.67 & 24.88 & 25.29 & 29.46 \\
\hline
\end{tabular}

to emphasize the strongest peaks of the phases. The Rietveld plot in $2 \theta$ range from 10 to $90^{\circ}$ of sample M3T5, which has the highest glass content of all samples, is shown in Fig. 3. Angular range from 3 to $10^{\circ} 2 \theta$ does not contain diffraction peaks and was not included in the Rietveld refinement. Diffratograms calculated using the Rietveld method reached an acceptable convergence to observed data (Table II). Weighted residue ( $R w p$ ) ranges from 6.2 to 8.1, and displays a slight decrease in each ceramic. Goodness of fit (square chi) ranges from 2.7 to 4.6 and follows the same trend of slight decrease with increasing temperature in each series of ceramic compositions.

Diopside $\left(\mathrm{CaMgSi}_{2} \mathrm{O}_{6}\right)$ is the only source of $\mathrm{Ca}$ among the experimental raw materials and promotes anorthite $\left(\mathrm{CaAl}_{2} \mathrm{Si}_{2} \mathrm{O}_{8}\right)$ formation in the ceramic bodies; increase in anorthite proportion is followed by a respective decrease in glass and mullite $\left(\mathrm{Al}_{6} \mathrm{Si}_{2} \mathrm{O}_{13}\right)$. Anorthite proportion increases with diopside content in the raw mixture, but there is no clear variation of anorthite content with increasing burning temperature. The introduction of over $15 \mathrm{wt}$.\% diopside gives rise to anorthite, which decreases the sintering range and the viscosity of the melt [3]. However, our results indicates that anorthite appears at even lower diopside content in the raw mixture. The $\mathrm{MgO}$ content of diopside was partitioned into the glass phase, as no Mg-bearing crystalline phase was recognized in the ceramic bodies. A residual amount of diopside was detected in the ceramic body prepared with the highest diopside content and fired in the lowermost temperature (M5T1; $20 \mathrm{wt} . \% \mathrm{di}, 1170{ }^{\circ} \mathrm{C}$ ).

Mullite content decreases with the amount of diopside in the raw mixture (Fig. 1), but there is an increase in mullite in M5 composition (maximum diopside content); higher burning temperature slightly favours mullite formation. The antagonic relation between anorthite and mullite is a consequence of decreasing $\mathrm{Al}_{2} \mathrm{O}_{3}: \mathrm{CaO}$ ratio, with increasing degree of substitution of feldspar by diopside. 


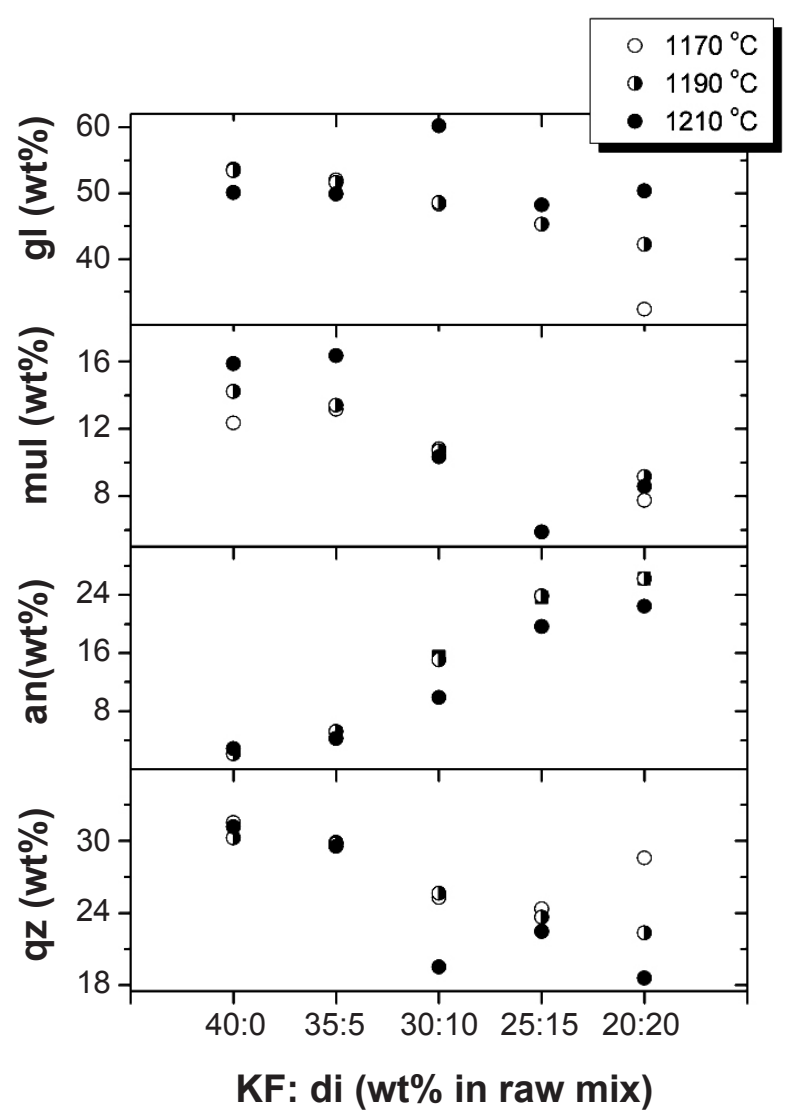

Figure 1: Phase composition of ceramic bodies in respect to KF:di ratio of the raw misture $(\mathrm{KF}=$ potassium feldspar; $\mathrm{di}=$ diopside; $\mathrm{qz}=$ quartz; an = anorthite; mul = mullite; $\mathrm{gl}=$ glass) and burning temperature.

[Figura 1: Composição das fases dos corpos cerâmicos em relação a razão $K F$ :di nas matérias-primas ( $K F=$ feldspato potássico; $d i$ = diopsídio; $q z=$ quartzo, an = anortita =; mul = mulita $; g l=$ vidro) e temperatura de queima.]

Potassium feldspar $\left(\mathrm{KAlSi}_{3} \mathrm{O}_{8}\right)$ was completely consumed in ceramic reactions in all ceramic bodies. The lack of potassium-bearing crystalline phases in the ceramic bodies and the direct relationship between potassium feldspar in the raw mixture and glass in the respective ceramic body indicates that $\mathrm{K}_{2} \mathrm{O}$ is partitioned towards the glass phase. The glass phase also contains the potassium provided by the illite present in the clay fraction of the raw mixture. $\mathrm{As}_{2} \mathrm{O}$ is the main flux in the raw mixture, progressive subtitution of feldspar by diopside causes a decrease in glass content in the ceramics.

The amount of quartz $\left(\mathrm{SiO}_{2}\right)$ steadily decreases with the increase in diopside content in the raw mixture. The high temperature polymorphs of $\mathrm{SiO}_{2}$ (cristobalite, tridymite) are lacking. The effect of temperature on the amount of quartz is less evident, as it remains constant for compositions M1, M2 and M4 for the three temperatures analyzed and there is a trend of decreasing quartz with increasing temperature for M3 and M5 (Figure 1). Quartz content of the raw mixtures was $20 \mathrm{wt} \%$, while in the ceramics it is in the range between 18.6 and $31.5 \mathrm{wt} . \%$, indicating that quartz was also formed

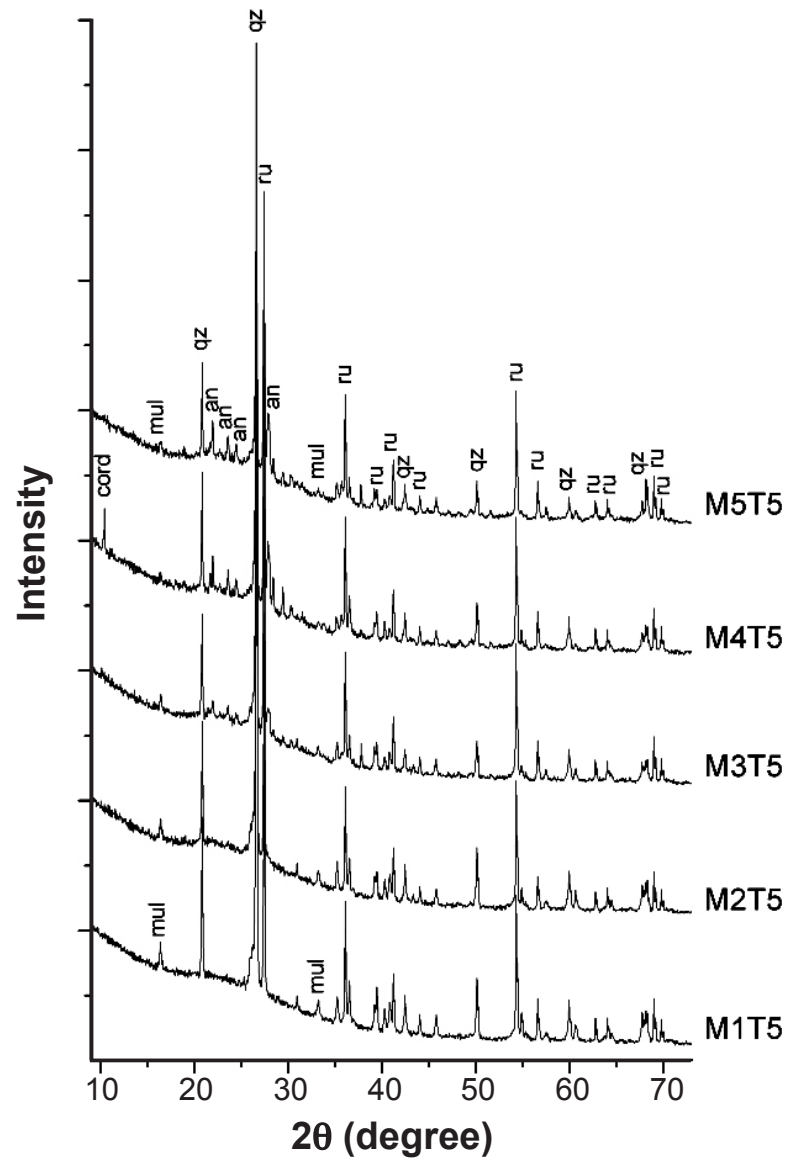

Figure 2: X-ray diffraction patterns $(\mathrm{CuK} \alpha)$ of ceramic bodies of all compositions, fired in the maximum temperature $\left(\mathrm{T} 5=1210{ }^{\circ} \mathrm{C}\right)$. Phases identified are: an = anorthite; mul = mullite; qz = quartz; cord $=$ cordierite; $r u=$ rutile (internal standard).

[Figura 2: Difratogramas de raios $X(\mathrm{CuK \alpha})$ dos corpos cerâmicos de todas as composições, sinterizados na temperatura máxima $(T 5=$ $1210^{\circ} \mathrm{C}$ ). As fases identificadas são: an = anortita; $m u l=$ mulita; $q z$ $=$ quartzo; cord $=$ cordierita $;$ rutilo $=r u($ internal standard $)$.

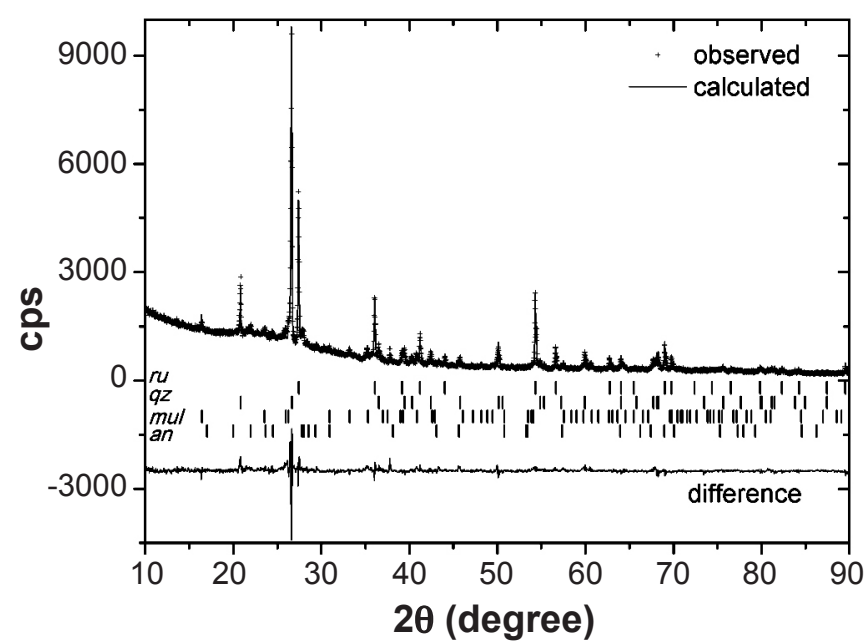

Figure 3: Rietveld plot of sample M3T5. Crystalline phases identified are rutile ( $r u$, internal standard), quartz $(q z)$, mullite (mul), anorthite (an).

[Figura 3: Diagrama de Rietveld da amostra M3T5. As fases cristalinas identificadas são rutilo ( $r$, padrão interno), quartzo (qz), mulita (mul) e anortita (an).] 
after thermal breakdown of feldspar.

Cordierite $\left((\mathrm{Mg}, \mathrm{Fe})_{2} \mathrm{Al}_{3}\left(\mathrm{Si}_{5} \mathrm{AlO}_{18}\right)\right)$ is present in the series M4 only; its amount is fairly low ( $<4$ wt.\%) and increases with increasing temperatures (Fig. 1, Fig. 2); this rather exceptional behaviour is possibly related to heterogeneities in the raw materials. The $\mathrm{SiO}_{2}-\mathrm{Al}_{2} \mathrm{O}_{3}-\mathrm{MgO}$ ternary system at $1 \mathrm{~atm}$ shows a sequence of cristobalite, mullite, corundum along its $\mathrm{SiO}_{2}-\mathrm{Al}_{2} \mathrm{O}_{3}$ join [28]. With increased $\mathrm{MgO}$ contents, there is a field of cordierite stability close to the center of the triangular phase diagram, slightly displaced toward the $\mathrm{SiO}_{2}$ apex. Therefore, cordierite formation is favored by increased $\mathrm{MgO}$ content.

There is a sharp contrast in the physical and mechanical properties of the ceramics produced with diopside-free (M1) and diopside-bearing (M2 to M5) raw mixtures (Table II), although there are no systematic trends in these properties with increasing diopside content in the raw mixture. Apparent porosity and water absorption are significantly higher in diopside-free series compared to the dipsidebearing series. Flexural resistance and linear retraction are higher in ceramics produced with diopside-bearing raw mixtures. Increased flexure resistance is related to the presence of anorthite, as a matrix composed of imbricated microcrystals is more resistant than a glassy one, as grain boundaries hinder crack-propagation. Porosity and water absorption decrease with increasing firing temperature in all series of ceramic composition (Table II), due the formation of the liquid (glass) phase, with increasing firing temperature.

A general mineral reaction for the studied mixture may be written as:

$$
\begin{aligned}
& 3 \mathrm{Al}_{2} \mathrm{Si}_{2} \mathrm{O}_{5}(\mathrm{OH})_{4}+4 \mathrm{KAlSi}_{3} \mathrm{O}_{8}+\mathrm{CaMgSi}_{2} \mathrm{O}_{6} \rightarrow \mathrm{Al}_{6} \mathrm{Si}_{2} \mathrm{O}_{13} \\
& +\mathrm{CaAl}_{2} \mathrm{Si}_{2} \mathrm{O}_{8}+16 \mathrm{SiO}_{2}+2 \mathrm{~K}_{2} \mathrm{O}+\mathrm{MgO}+6 \mathrm{H}_{2} \mathrm{O}
\end{aligned}
$$

This general reaction combines all raw materials (kaolinite + potassic feldspar + diopside) and produces a mixture of mullite, anorthite, silica (both as quartz and glass), water, and of the oxides which are present only in the glass phase $\left(\mathrm{MgO}, \mathrm{K}_{2} \mathrm{O}\right)$, as they are present in the raw materials but not in the crystalline phases of the ceramic bodies.

\section{CONCLUSIONS}

Phase composition of the experimental ceramic bodies is more strongly controlled by the proportion of potassium feldspar and diopside in the raw mixture, while temperature in the considered range $\left(1170-1210{ }^{\circ} \mathrm{C}\right)$ is less effective in controlling phase formation. Diopside favours anorthite formation. Potassium feldspar favours glass and mullite formation in the ceramic bodies. Cordierite could be favoured by increased $\mathrm{MgO}$ content of the system, and its presence in mixture M4 is probably related to heterogeneity of the raw mixture, such as a slightly higher content of diopside in diopside-rich rock. The addition of diopside partially replacing the potassic feldspar, reduces water absorption and porosity of the ceramic bodies, and provides higher values of flexural resistance. The temperature rise at a constant proportion of diopside collaborates with decreased water absorption and porosity. The incorporation of diopside provides white burning as traditional ceramic. The addition of only $5 \%$ of diopside replacing the potassic feldspar, permits obtaining porcelain at lower temperatures than those used in the ceramic industry, collaborating with the reduction of energy consumption.

\section{ACKNOWLEDGEMENTS}

The authors acknowledge L. A. Gobbo (Panalytical) and L. Sousa for their help with XRD data acquisition. L. Kuzmickas is grateful to Lagoa Matérias-Primas (Castro Alves, BA), Institute for Technological Research of S. Paulo (IPT) and Geosciences Institute of S. Paulo University (USP-IGc) for financial support. The authors are grateful for the careful review of the both the reviewer and the Editor.

\section{REFERENCES}

[1] Y. I. Alekkev, V. I. Vereshchagin, E. A. Karpova, Glass Ceramics 47 (1990) 357.

[2] Y. I. Alekeev, A. E. Abakumov, E. V. Abakumova, Glass Ceramics 52 (1995) 94.

[3] G. M. Azarov, A. S. Vlasov, E. V. Maiorova, M. A. Oborina, Glass Ceramics 52 (1995) 216.

[4] Y. I.Alekeev, Glass Ceramics 54 (1997) 394.

[5] K.S. Kostikov, V. M. Pogrebenkov, V. I. Vereshchagin, The $5^{\text {th }}$ Russian-Korean Int. Symp. Sci. Technol. 2 (2001) 187.

[6] F. Kara, M. Cavac, Conferencias Generales Ponencias Posters, Cartellon España, Tomo III (2002).

[7] L. Sanchez-Munoz, E. Cerisuelo, E. Longo, J. B. Carda, Cerâmica 48 (2002) 137.

[8] A. P. Novaes de Oliveira, D. Hotza, M. Peterson, A. Oliveira da Silva, R. Piccoli, VII World Cong. Ceramic Tile Quality 3 (2002) 169.

[9] R. Piccoli, A. P. N. Oliveira, A. Mexias, R. Figueira, O. R. K. Montedo, F. M. Bertan, $17^{\circ}$ Congresso Brasileiro de Engenharia e Ciência dos Materiais, Foz do Iguaçu, PR (2006) 883.

[10] L. L. Freire de Miranda, G. A. de C. Lopes, Pegmatitos quartzo-feldspáticos de Castro Alves, CBPM, Salvador, BA (2008) 10.

[11] V. M. Conceição Filho, M. D. Moreira, Depósitos de argila do Recôncavo Baiano: geologia e potencialidade econômica, CBPM, Salvador, BA (2001) 10.

[12] H. M. Rietveld, Acta Cryst. 22 (1967) 151-152.

[13] H. M. Rietveld, J. Appl. Cryst. 2 (1969)65-71.

[14] L. B. McCusker, R. B. Von Dreele, D. E. Cox, D. Louer, P. Scardi. J. Appl. Cryst. 32 (1999) 36-50.

[15] A. F. Gualtieri, J. Appl. Cryst. 33 (2000) 267.

[16] International Standard for Organization, ISO 10545:

Part 3 (1995) 1.

[17] International Standard for Organization, ISO 10545:

Part 4 (1995) 1. 
[18] E. J. Sonnveld, J. W. Visser, J. Appl. Cryst. 8 (1975)1.

[19] A. Savitsky, M. J. E. Golay, Anal. Chem. 36 (1964) 1627-1639.

[20] R. J. Hill, C. J. Howard, J. Appl.Cryst. 20 (1987) 467.

[21] T. M. Sabine, Acta. Cryst. A44 (1988) 368.

[22] K. Sugiyama, Y. Takeuchi, Zeit. Kristallographie194 (1991) 305.

[23] S. M. Antao, I. Hassan, J. Wang, P. L. Lee, B. H. Toby, Can. Miner. 46 (2008) 1501.

[24] R. J. Angel, M. A. Carpenter, L. W. Finger, Am. Miner.
75 (1990) 150.

[25] S. Durovic, Chemicke Zvesti 23 (1969) 113.

[26] M. Prencipe, M. Tribaudino, A. Pavese, A. Hoser, M. Reehuis, Can. Miner. 38 (2000) 183.

[27] E. Haussuehl, V. L. Vinograd, T. F. Krenzel, J. Schreuer, D. J. Wilson, J. Ottinger, Zeit. Kristallographie 226 (2011) 236.

[28] E. Levin, C. R. Robbins, H. F. McMurdie, "Phase diagrams for ceramists", Am. Ceram. Soc. (1964) 601.

(Rec. 18/06/2012, Rev. 15/12/2012, 14/01/2013, Ac. 22/04/2013) 